\title{
The Effects of Research-Inquiry Based Learning on the Scientific Reasoning Skills of Prospective Science Teachers
}

\author{
Ibrahim Yuksel \\ Correspondence: Ibrahim Yuksel, Gazi University, Faculty of Education, Department of Mathematics and Science \\ Education, Ankara, Turkey.
}

Received: February 12, 2019

Accepted: March 25, 2019 Online Published: March 26, 2019

doi:10.11114/jets.v7i4.4020

URL: https://doi.org/10.11114/jets.v7i4.4020

\begin{abstract}
The aim of this study is to investigate the effect of research-inquiry-based learning approach on the Scientific Reasoning Skills of Science Education Prospective Teachers in the Nature of Science and Science History Course. The study was designed as a single group pre-test - post - test model. The study group consisted of 31 prospective teachers in the $3 \mathrm{rd}$ grade of Science Education program in a public university in the spring term of 2017-2018 academic year. For the scientific reasoning skills of prospective teachers "Scientific Reasoning Skills Test - SRST" was measured as a pre-test, then the Nature of Science and Science History course was conducted with the Research-Inquiry Based Learning Approach and SRST was applied as a final test. This test consists of 7 sub-dimensions and contains a total of 26 items. The findings of the sub-problems of the study can be expressed as follows; a significant difference was found between the SRST pre-test total scores and post-test total scores in favor of the post-test total scores according to the sub-dimensions of proportional thinking, correlative thinking and hypothetical thinking. There was no significant difference in the post-test total scores according to the sub-dimensions of conservation laws, identifying and controlling variables, combinatorial thinking and probabilistic thinking. There was no significant difference between SRST pre-test and post-test total scores of man and woman students. A significant difference was found only in the sub-dimension of combinatorial thinking in the total scores of the sub-dimensions of SRST.
\end{abstract}

Keywords: research-inquiry based learning, scientific reasoning skills

\section{Introduction}

One of the most appropriate ways for students to understand the nature of science and scientific content is that they live as much as possible the scientific argumentation and reasoning process in educational contexts similar to the socio-cultural contexts of scientists (Koseoglu, Tumay and Ustun, 2010). Countries can develop with reasoning and science. The place and importance of science in the field of education have been understood in earlier periods, science curricula have been organized and developed to our day.

To understand and know the nature and history of science, to learn the development and nature of science by using appropriate methods and techniques will contribute to the development of reasoning skills.

One of the most important subjects in science education is teaching the nature and history of science as a part of science education in recent years (Tasar, 2003). Teaching the nature of science should be considered as a cognitive learning product (Kucuk, 2006). In cognitive development, it is important to determine the level of reasoning skills, which are expected to have during formal operational stage, and in which efficiency is used, in terms of cognitive development (Ates, 2002). In addition, several studies in Turkey show that scientific reasoning skills of secondary school, high school and university students are relatively low (Ates, 2002; Demirbas and Ertugrul, 2012).

In order to be able to educate qualified and productive individuals, science education should be applied more efficiently in classes. Among the central aims of science education, the necessity of students to understand the nature of science and how scientific reasoning is made is emphasized in the last century (Schen, 2007). Musheno and Lawson (1999) also puts the scientific reasoning of "if ...... and.....then .........so" on the basis of understanding the nature of science. If the nature of science is to be taught to students, the experiences of scientists can only be experienced by also teaching their mental processes. Explaining the basic scientific reasoning patterns, showing how to use the pattern to find answers to scientific questions, using scientific reasoning patterns in teaching the observable and unobservable contexts will provide a better understanding of the nature of science. 
According to Cepni (2008), the formal operational stage characteristics of Piaget; the period of formal operations, the highest level of cognitive development, covers 11 years and beyond. The cognitive process in human beings in the formal operational stage is as follows:

Hypothetical Thinking: It is a process of thinking that enables the development of possible solutions to solve a problem in daily life or education. It's expressed with a general sentence structure as"if and.....then ..so".

Identifying and Controlling Variables: The factors that may affect an observed event are called variable. This process consists determination, identification and control of dependent and independent factors affecting the continuity of the situation in testing the hypothesis, event or concept.

Proportional Thinking: It's the cognitive process skills used in understanding the ratio between the parameters and comparing the relationships. This skill is the realization of what kind of ratio is among the parameters that affect any event.

Probabilistic Thinking: It is the ability to calculate all possible probabilities in all stages of an event or assumption from its first state to its last state.

Combinational Thinking: It is the cognitive ability that systematically takes into consideration all the theoretical or experimental relationships that are expected to be.

Correlational Thinking: It means establishing a link between a variable object and another variable object. It is a process that is expressed as considering what kind of relationships, connections are there or are not there between the examined situations or situations.

A research and inquiry-based learning environment should be organized in order for students to obtain both meaningful and permanent information in science. In this learning environment, students should be individuals who are interested in research and exploration, such as scientists, who are enthusiastic about science, learn by experiencing by doing it (Ministry of National Education, 2013).

A research-inquiry based learning approach is adopted in the science curriculum in 2013. This approach has not been transferred to the courses by many teachers, and the research that the teachers use in their classes does not overlap with the research-inquiry accepted in the innovation movements (Senturk, 2017; Unisen \& Kaya, 2015). In the Nature of Science and Science History course, research-inquiry-based learning approach and meaningful learning can be achieved with the teaching activity made in accordance with the cognitive development periods of the students. Hence, in this study by analyzing the effects of research-inquiry based learning approach on the scientific reasoning skills of prospective teachers studying in the 3rd grade in Science Education in the Nature of Science and Science History course, the development of scientific reasoning skills of the students during the formal operational stage was examined.

\section{Problem Statement}

The general problem statement of this study can be expressed as "The Effect of Research-Inquiry Based Learning Approach on the Scientific Reasoning Skills of Prospective Science Education Teachers in the Nature of Science and Science History course."

\section{Sub-Problems}

1. Is there a difference between SRST pre-test total scores and post-test total scores in the Nature of Science and Science History course using a research-inquiry based learning approach?

2. Is there a difference between the pre-test total scores and the post-test total scores in terms of the SRST sub-dimension test score in the Nature of Science and Science History course using a research-inquiry-based learning approach?

3. Is there a difference between the genders in terms of the total test score of the SRST post-test in the Nature of Science and Science History course using a research-inquiry based learning approach?

4. Is there a difference between the genders in terms of the total test score of the SRST post-test sub-dimension in the Nature of Science and Science History course using a research-inquiry based learning approach?

\section{Method}

A single-group pre-test post-test model was used to examine the effect of the Nature of Science and Science History course taught with research-inquiry based learning approach on the students' scientific reasoning skills. The only difference that separates the semi-experimental method used in this study from the real experimental method is that the sample is not generated by random assignment. This is because the existing system does not allow this. There is only one class of grade 3 students in Science Education program in the selected sample in this study. Although Karasar (2013) recommends different applications of this method, a design based on pre- test - post-test applications on single group is used in this study. According to Karasar (2013), in the single group pre-test post-test model, an independent variable is applied to a randomly selected group. There are both pre-experiment (pre-test) and post-experiment (post-test) 
measurements. $\mathrm{O}_{1.2}>\mathrm{O}_{1.1}$ is considered to be due to "X". The symbolic view of the model is as follows in Table 1.

Table 1. Symbolic View of Single Group Pre- test Post-test Model

\begin{tabular}{|l|l|l|l|}
\hline $\mathrm{G}_{1}$ & $\mathrm{M}_{1.1}$ & $\mathrm{X}$ & $\mathrm{M}_{1.2}$ \\
\hline
\end{tabular}

*G: Group, X: Independent Variable Surface, M: Measurement, Observation

The main feature of all experimental research is that independent variables can be controlled (McMillan, 2000). In this study, "Research-inquiry based learning approach" the effect of which was analyzed on experimental groups was taken as an independent variable. The 7 activities aimed at improving formal reasoning were applied in the nature of science lesson, and at the beginning and end of the semester, the effects of these activities on the development of scientific reasoning skills were examined.

\section{Study Group}

The study group of the research was composed of 31 prospective teachers who studies in the 3rd year of Science Education program in a State University in the 2017-2018 Academic Year Spring Semester and took the Nature of Science and Science History course.

\section{Data Collection Tools}

Some questions were adapted for university students and the Cronbach Alpha reliability coefficient of the Scientific Reasoning Skills Test (SRST) developed by Yuksel (2015) was found as .76. For Cronbach's Alpha values, a value of .76 was found to be a reliable value for the test (Kayis, 2014).

\section{Scientific Reasoning Skills Test (SRST)}

Scientific Reasoning Skills Test (SRST) consists of a total of seven sub-dimensions, understanding the conservation laws and the six dimensions expected to be included in the individual during the formal operational stage. The questions in the sub-dimensions of the SRST are presented in Table 2.

Table 2. SRST Sub-Dimensions Questions

\begin{tabular}{ll}
\hline SRST Sub-Dimensions Questions & Questions \\
\hline Conservation Laws & $1,2,3$ \\
Proportional Thinking & $4,5,6,7$ \\
Identifying and Controlling Variables & $8,9,10,11$ \\
Combinational Thinking & $12,13,14,15$ \\
Correlational Thinking & $16,17,18,19$ \\
Probabilistic Thinking & $20,21,22,23$ \\
Hypothetical Thinking & $24,25,26$ \\
\hline
\end{tabular}

\section{Data Analysis}

In the analysis of the data, data entry was provided by coding 1 for the correct answers that the students answered, and 0 for each answer they left blank and they answered wrong. The correct and incorrect answers that the students answered for each question were analyzed with SPSS analysis program. The pre-test and post-test were analyzed by dependent samples $\mathrm{t}$ - test and the gender variable was analyzed by $\mathrm{t}$ - test for independent samples.

\section{Findings and Discussion}

3.1. Is There a Difference Between SRST Pre-Test Total Scores and Post-Test Total Scores in the Nature of Science and Science History Course Using a Research-Inquiry Based Learning Approach?

The total score of the SRST pre-test in the Nature of Science and Science History course using a research-inquiry based learning approach is given in Table 3.

Table 3. SRST Pre-Test Total Scores

\begin{tabular}{llll}
\hline Test & $\mathrm{N}$ & Mean Score $(\overline{\mathrm{X}})$ & $\mathrm{p}$ \\
\hline Pre-test & 31 & 15.55 & .00 \\
Post-test & 31 & 19.52 & \\
\hline
\end{tabular}

Significant differences were observed between the total scores of SRST pre-test and post-test $(\mathrm{p}=.00, \mathrm{p}<.05)$. SRST post-test total scores were found to have a higher mean score. 
3.2. Is There a Difference Between The Pre-Test Total Scores and The Post-Test Total Scores in Terms of the SRST Sub-Dimension Test Score in the Nature of Science and Science History Course Using a Research-Inquiry Based Learning Approach?

The difference between the pre-test total scores and the post-test total scores in terms of the total test scores of the SRST sub-dimensions is given in Table 4.

Table 4. Pre-test Post-test Total Scores of SRST Sub-dimensions

\begin{tabular}{lllll}
\hline Sub-dimensions & $\mathrm{N}$ & Pre-test Mean Score & Post-test Mean Score & $\mathrm{p}$ \\
\hline Conservation Laws & 31 & 2.26 & 2.52 & .22 \\
Proportional Thinking & 31 & 2.94 & 3.77 & .00 \\
Identifying and Controlling Variables & 31 & 2.68 & 2.87 & .23 \\
Combinational Thinking & 31 & 3.26 & 3.36 & .60 \\
Correlational Thinking & 31 & 1.07 & 2.45 & .00 \\
Probabilistic Thinking & 31 & 3.07 & 3.45 & .12 \\
Hypothetical Thinking & 31 & .23 & 1.00 & .00 \\
\hline
\end{tabular}

Between the SRST pre-test total scores and the post-test total scores of the research-inquiry-based learning approach; according to proportional thinking $(\mathrm{p}=.00, \mathrm{p}<.05)$, correlational thinking $(\mathrm{p}=.00, \mathrm{p}<.05)$ and hypothetical thinking $(\mathrm{p}=.00, \mathrm{p}<.05)$ there was a significant difference in favor of the post-test total scores. According to the sub-dimensions scores of conservation laws $(\mathrm{p}=.22, \mathrm{p}>.05)$, identifying and controlling variables $(\mathrm{p}=.23, \mathrm{p}>.05)$, combinational thinking $(\mathrm{p}=.60, \mathrm{p}>.00)$ and probabilistic thinking $(\mathrm{p}=.12, \mathrm{p}>.05)$ there was no significant difference in the post-test total scores.

3.3. Is There a Difference Between the Genders in Terms of SRST Post-Test Total Scores in the Nature of Science and Science History Course Using a Research-Inquiry Based Learning Approach?

The difference between genders in terms of SRST post-test total scores in the Nature of Science and Science History course using a research-inquiry-based learning approach is given in Table 5.

Table 5. SRST Post-test Total Scores According to Genders

\begin{tabular}{|c|c|c|c|}
\hline Gender & $\mathrm{N}$ & & $\mathrm{p}$ \\
\hline Woman & 24 & 19.13 & .36 \\
\hline Man & 7 & 20.86 & \\
\hline
\end{tabular}

There was no significant difference between the genders in terms of SRST post-test total scores $(\mathrm{p}=.36, \mathrm{p}>.05)$.

3.4. Is There a Difference Between The Genders in Terms of The SRST Sub-Dimension Test Score in the Nature of Science and Science History Course Using a Research-Inquiry Based Learning Approach?

Table 6 shows the difference between the genders in terms of the SRST sub-dimension test score in the Nature of Science and Science History course using a research-inquiry based learning approach.

Table 6. SRST Sub-dimensions Scores According to Genders

\begin{tabular}{lllll}
\hline Sub-dimensions & $\mathrm{N}$ & Mean Score of Women & Mean Score of Men & $\mathrm{p}$ \\
\hline Conservation Laws & 31 & 2.50 & 2.57 & .83 \\
Proportional Thinking & 31 & 3.75 & 3.86 & .57 \\
Identifying and Controlling Variables & 31 & 2.75 & 3.29 & .06 \\
Combinational Thinking & 31 & 3.21 & 3.86 & .03 \\
Correlational Thinking & 31 & 2.63 & 1.85 & .24 \\
Probabilistic Thinking & 31 & 3.29 & 4.00 & .01 \\
Hypothetical Thinking & 31 & .96 & 1.14 & .73 \\
\hline
\end{tabular}

In the sub-dimension scores between the post-test total scores according to gender in the Nature of Science and Science History course using research-inquiry based learning approach, for Conservation laws $(p=.83, p>.00)$, proportional thinking $(\mathrm{p}=.57, \mathrm{p}>.05)$, identifying and controlling sub-dimension score, there was no significant difference in the post-test total scores. There was a significant difference in favor of post-test total scores according to the sub-dimensions of combinational thinking $(\mathrm{p}=.03, \mathrm{p}<.05)$ and probabilistic thinking $(\mathrm{p}=.01, \mathrm{p}<.05)$. 


\section{Result and Recommendations}

According to the results, there was a significant difference between SRST pre-test total scores and post-test total scores of prospective Science Education teachers. SRST post-test total scores were found to have a higher mean score.

There was a significant difference between the SRST pre-test and post-test total scores of the research-inquiry based learning approach in favor of the post-test total scores according to correlational thinking and hypothetical thinking sub-dimensions. There was no significant difference in the post-test total scores according to conservation laws, identifying and controlling variables, combinational thinking and probabilistic thinking sub-dimensions.

According to gender, there was no significant difference in the total scores of SRST in the Nature of Science and Science History course using a research-inquiry based learning approach. According to gender, between the post-test total score of SRST; there was no significant difference in the post-test total scores according to the total scores of conservation laws, proportional thinking, identifying and controlling variables, correlational thinking and hypothetical thinking sub-dimensions. There was a significant difference in favor of post-test total scores according to the sub dimensions of combinational thinking and probabilistic thinking. It was seen in the study of Yuksel and Tarakci (2018) on middle school students that women had higher average scores among genders according to Science lesson SRST total scores. In the sub-dimensions, women had higher average scores in identifying and controlling the variables, combinational thinking and correlational thinking. It was seen that there was a significant difference between the man and woman students in terms of corrected post-test total scores of identifying and controlling the variables and hypothetical thinking sub-dimensions (Yuksel, 2015). For the other sub-dimensions, no significant difference was found between the woman and man students in terms of the corrected post-test total scores. In another study, Yaman and Karamustafaoglu (2006) concluded that the logical thinking abilities of prospective teachers did not change according to gender.

Teachers have an important role in the development of the formal operational stage skills of the students. First of all, teachers should have sufficient knowledge about what is the place of scientific reasoning in cognitive development with research-inquiry based learning approach, in which sub-dimensions the students are insufficient and what skills are required by this sub-dimension level. Studies to contribute to the development of these skills should be included while planning educational activities.

\section{References}

Ates, S. (2002). Comparison of scientific thinking skills of 3rd grade students in classroom teaching and science teaching. The report presented in V. National Science and Mathematics Education Congress. 16-18 September 2002. METU, Ankara. Access address: http://old.fedu.metu.edu.tr/ufbmek-5/netscape/b_kitabi\%5Cb_kitabi.htm

Cepni, S. (Ed.). (2008). Science and technology teaching (Fen ve teknoloji ögretimi in Turkish). Ankara: Pegem A. ISBN: 975-8792-90-3

Demirbas, M., \& Ertugrul, N. (2012). Examining the realization status of the skills expected to be gained during Piaget's formal operational stage in science and technology course. 2012 Kalem Education and Health ServicesFoundation. Access address:

http://kalemacademy.com/Cms_Data/Sites/KalemAcademy/Files/KalemAcademyRepository/sayilar/Sayi3_04Fve TeknolojiDersine_.pdf

Karasar, N. (2013). Scientific research method (Bilimsel arastırma yöntemi in Turkish). 28th Edition. Ankara: Nobel. ISBN: 6055426583

Kayis, A. (2014). Reliability analysis. SPSS applied multivariate statistical techniques (SPSS uygulamalı çok değiş̧kenli istatistik teknikleri). Seref Kalayci (Ed.), Reliability analysis. Ankara: Asil. ISBN: 975-9091-14-3

Koseoglu, F., Tumay, H., \& Ustun, U. (2010). Discussions about development of the nature of science teaching professional development package and application to prospective teachers. Ahi Evran University Kirsehir Education Faculty Journal, 11(4), December Special Issue, 129-162. Access address: http://kefad.ahievran.edu.tr/Kefad/ArchiveIssues/Detail/b6793b57-ba54-e711-80ef-00224d68272d

Kucuk, M. (2006). A study toward teaching the nature of science for seventh grade primary students. PhD Thesis, Karadeniz University, Institute of Science and Technology, Trabzon. Access address: https://tez.yok.gov.tr/UlusalTezMerkezi/tezSorguSonucYeni.jsp Thesis number: 183041

Mcmillan, J. H. (2000). Educational Research. USA: Fundamentals for the Consume, Longman. ISBN: 0205372473

Ministry of National Education (MONE). (2013). Primary Education Institutions (Primary Schools and Secondary Schools) Science Courses (3, 4, 5, 6, 7 and 8 Grades) Curriculum The Ministry of Education. Ankara. Access address: https://docplayer.biz.tr/18927435-Zeka-oyunlari-dersi-ogretim-programi.html 
Musheno, B. V., \& Lawson, A. E. (1999). Effects of learning cycle and traditional text on comprehension of science. Journal of Research in Science Teaching, 36(1), 23-37. Access address: http://www.public.asu.edu/ anton1/AssessArticles/Articles/Learning\%20Cycles/Effects\%20of\%20learning\%20ccl e.pdf

Schen, M. S. (2007). Scientific reasoning skills development in the introductory biology courses for undergraduates. The Ohio State University, USA. Access address: http://adsabs.harvard.edu/abs/2007PhDT. $192 \mathrm{~S}$

Senturk, O. (2017). An evaluation of the third grade sciences curriculum in elementary school. Master's thesis, Marmara University, Institute of Education, Istanbul. Access address:

https://tez.yok.gov.tr/UlusalTezMerkezi/tezSorguSonucYeni.jsp Thesis number:469652

Tasar, M. F. (2003). Teaching history and the nature of science in science teacher education programs. Pamukkale Üniversitesi Ë̆itim Fakültesi Dergisi, 13(1), 30-42. Access address: http://pauegitimdergi.pau.edu.tr/Makaleler/1482465516_3-teaching\%20history\%20and\%20the\%20nature\%20of 20science.pdf

Unisen, A., \& Kaya, E. (2015). An investigation into teachers' views on placement of science education in primary 3rd grade. Adlyaman University Journal of Institute of Social Sciences, 546-571. Access address:https://www.researchgate.net/publication/291558372_FEN_BILIMLERI_DERSININ_ILKOKUL_UCUC U_SIIF_PROGRAMINA_ALINMASIYLA_ILGILI_OGRETMEN_GORUSLERININ_DEGERLENDIRILMESI

Yaman, S., \& Karamustafaoglu, S. (2006). Investigation Of Logical Thinking Skills And Attitudes Scale Towards Chemistry Of Prospective Teachers. Journal of Erzincan Faculty of Education, 8(1), 91-106. Access address: http://dergipark.gov.tr/erziefd/issue/6004/80066

Yuksel, I. (2015). Examination the effect of activities based on prediction observation explanation and acceleration of cognitive development on science teacher candidates' reasoning skills. PhD Thesis, Gazi University Institute of Education, Ankara. Access address: https://tez.yok.gov.tr/UlusalTezMerkezi/tezSorguSonucYeni.jsp Thesis number: 378247

Yuksel, I., \& Tarakci, B. (2018). An investigation of the scientific reasoning skills expected to be gained in the formal operational stage in the science course in secondary schools. V. International Multidisciplinary Studies Symposium (ISMS) (16-17 November 2018, Ankara-Turkey). Access address:

https://drive.google.com/file/d/12oGS-zboyVoU7tdNApmMRbi94agTEk9G/view

\section{Copyrights}

Copyright for this article is retained by the author(s), with first publication rights granted to the journal.

This is an open-access article distributed under the terms and conditions of the Creative Commons Attribution license which permits unrestricted use, distribution, and reproduction in any medium, provided the original work is properly cited. 